\title{
Effectiveness Through Crime Investigation Complaint Case Holds In Central Java Police Jurisdiction
}

\author{
Yuniar Pradhana Mukti ${ }^{1}$ and Gunarto ${ }^{2}$ \\ Abstract. Problems of criminal law, especially the problem of crime, abuse and \\ all kinds of acts that fall into the category of offense is now becoming one of \\ the crucial problems and quite tricky to overcome. In line with the task of \\ institution Indonesian National Police (INP) in an effort to maintain security \\ and order and enforcement of justice citizens, then the effectiveness of the \\ investigation and the disclosure of a criminal offense it is important to be \\ maximized. The aim is to give meaning to the rule of law in Indonesia that \\ provides fairness, expediency and legal certainty. \\ Keywords: Criminal Law; Police; Effectiveness; Law Enforcement
}

\section{Introduction}

Indonesia has set every problem in the Constitution of the Republic of Indonesia Of 1945 , which confirmed that Indonesia is a country of law. ${ }^{3}$ In the science of sociology of law, there are four elements that influence the effectiveness of the rule of law in society, among other things: the legal norms / rules themselves, law enforcement personnel, facilities and infrastructure, and public awareness (social culture). The four elements are very important for its function is maximized so that the law can be an effective force in the community, with the goal to be achieved demikan three laws, namely: fairness, expediency and legal certainty.

The effectiveness of the rule of law can be seen by the amount of the percentage of public complaints that were successfully followed up by the police in Central Java Police. Data on the Central Java Police Sub Itwasda Dumasan on January 1, 2018 until April 2018 receivedthe number of public complaints (dumas) 239 (two hundred thirty nine) letter or complaint, and who were successfully followed up as much as 206 (two hundred and six) cases of complaints. It shows that $86 \%$ of cases of public complaints can be handled well, while showing a good performance of the police anyway. During this time, the performance of the police in the eyes of society and the law became an interesting topic for research.

Central Java Police Duties are considered the most effective in the occurrence of criminal acts in the handling and disclosure of a criminal offense is a repressive task of conducting the investigation of crimes and law violations according to the provisions in the legislation. As for the process, as there are public complaints (dumas) then the Central Java Police Regulation of the Director (PERDIR) General Criminal Investigation Central Java Regional Police No. 2 Of 2015 On Case Complaint degree.

PERDIR Criminal Investigation General Regional Police Central Java No. 2 Of 2015 About Degree Complaint Cases published as an activity analysis of complaints coming to the police in an attempt to create an investigation that is professional,

\footnotetext{
${ }^{1}$ Student of Masters (S2) of Law Faculty of Law Unissula Semarang email: mpradhana@gmail.com

${ }^{2}$ Professor of Faculty of Law UNISSULA Semarang

${ }^{3}$ Article 1 (3) of the Constitution of the Republic of Indonesia 1945
} 
proportionate, transparent and accountable so that in later materialized guarantee service quality investigation to the fullest and can eliminate or reduce the grievance / complaints from the public.

\section{Research Methods}

This type of research used in this research is descriptive analysis method, the research done by researching library materials (secondary data) or legal research library ${ }^{4} A n d$ described in the analysis and discussion.

According Soerjono Soekanto and Sri Mamudji, normative legal studies include research into the principles of law, the degree of synchronization of law ${ }^{5}$ The research approach used research approach usedin this research is the empirical legal research or so-called empirical juridical. In this study, the law conceived as an empirical phenomenon that can be observed in real life.

The data used are primary and secondary data. To obtain primary data researchers refer to data or facts and case law directly obtained through research in the field, including a description of the respondents related to the object of research and practice that can be seen and associated with the object of research. While the secondary data is done by means of a literature study.

The data collection is focused on the present, so that in this study is not distorted and blurred in the discussion, namely literature, Observations And Interviews

This study uses the Research Library (literature study) that the collection of data obtained from sources of literature, scientific papers, legislation and other written sources relating to the matter being investigated as a theoretical basis. From this research data obtained so-called secondary data. Data collection and observation of phenomena in the field prior to the study.

In a study conducted interviews with informants interviews with the guided-free way. Samples were taken using a non-purposive sampling method, the sample selection this way ignoring the principles of probability and expected results is only a rough idea about a situation regarding the effectiveness of Crime Investigation Complaint Held Through Case in Central Java Jurisdiction.

Data analysis method used was descriptive qualitative, ie the decomposition of data analysis that starts on information obtained from the respondents to achieve clarity issues to be discussed. From this analysis it can be seen the effectiveness of the legal system that is instructive to the public in knowing the effectiveness of Investigation Crime Complaint Held Through Case Central Java Police Jurisdiction.

As a way to draw conclusions from the research that has been collected, data analysis method used is a qualitative Normative. Normative for this study starts from the regulations - regulations that exist as a positive legal norms, while qualitative data analysis means that the starting point on the information obtained from the respondents to achieve clarity issues to be discussed.

\footnotetext{
${ }^{4}$ Ediwarman,2010. Monograf Metodologi Penelitian Hukum Medan: Program Pascasarjana Univ. Muhammadiyah Sumatera Utara Medan p. 24

${ }^{5}$ Soerjono Soekamto dan Sri Mamudji 2001 Penelitian Hukum Normatif Suatu Tinjauan Singkat Raja Grafindo Persada. Jakarta p. 13-14
} 


\section{Results And Discussion}

\subsection{Reason Publication of the General Criminal Investigation Perdir Central Java Regional Police No. 2 Of 2015 About Degree Complaint Cases}

Case file handling process starting from receipt of public complaints by part of the Integrated Police Service Center (IFMS). IFMS tasked with providing police services to the community in the form of first reception and handling of reports / complaints, the service assistance / help police, together with the related functions went to the crime scene (TKP) to carry out the crime scene security and in accordance with applicable laws and regulations. IFMS consists of three (3) units and is based on the division of time (Ploeg). Each unit is led by Head IFMS IFMS and is assisted by three (3) Head units and twelve (12) Part of the unit.

Every day there are five (5) public complaints or police reports are entered. Every incoming police report, IFMS manually distribute to Adj. The distribution of the manual by visiting the relevant leaders / parties directly would create a risk of delay in submission. In the visible, this time appointing investigators by hand, so that the visible can not know the caseload handled by the investigator and can not do direct monitoring the handling of cases handled by each investigator, usually investigators could gain time to immediately equip the administration investigation, so that the handling of the case becomes increasingly longer.

Public complaint data indicates the number of reports on complaints to be handled by the Central Java Police. Therefore, improvement of the pattern of public service, especially in Central Java Police Complaints Service Center is a necessity that can not be negotiable and strategic value in order to reform the Police service to the community. The problems above have explained, fast and precise criteria for handling cases of public complaints by the Central Java Police is one indicator of the passage of the Police reform in community service.

To realize the quality of police personnel are professional, disciplined, accurate and ethical, Central Java Police has implemented changes to build a new culture, ranging from changes in physical appearance chamber member services more comfortable impression. With this physical appearance, people who come in complaining of the problem will find that they are not mistaken to come denounce central issues it faces. In addition, the appearance changes also followed by changes in the behavior of the antagonists into a waitress apparatus populist, from the arrogant be humanist, and from authoritarian become aspirational. Central Java Police also make a paradigm shift of thinking (mindset) include: from closed to transparent, from vertical accountability into public accountability, and of monologues into Dialogic ${ }^{6}$,

Based on the interview above can be affirmed that the effort to revamp the public service complaints is one tool to restore the image of the Police into an institution that can be trusted community. General Criminal Investigation Perdir Central Java Regional

\footnotetext{
${ }^{6}$ Interview with Ipda Totok G SUBDIT III Participants Central Java Police Complaints title On Date August 4th 2018
} 
Police No. 2 of 2015 concerning Complaint Case Holds issued to accommodate the creation of good service quality, and it is also one of reflection changes in work culture of the police in serving the public complaints in the context of good goverment and clean governance.

\subsection{Procedures for Crime Investigation Complaint Held Through Case in Central Java Police Jurisdiction Based On Perdir General Central Java Regional Police No. 2 Of 2015 About Degree Complaint Cases}

Efforts to reform the public service complaints made by the Central Java Police can not be released from police duties. Main Tasks public complaint service itself is supported by the General Criminal Investigation Perdir Central Java Regional Police No. 2 of 2015 concerning Complaint Case Holds that aims to maintain security and public order, enforcing the law, and provide protection, shelter, and service to the community.

Degree complaint case has the meaning specified in Article 1, paragraph 7 of the General Criminal Investigation Perdir Central Java Regional Police No. 2 of 2015 concerning Complaint Case title, which means:

"degree is a degree that the complaint case be implemented in connection with the letter of complaint from the public about the criminal case, to determine whether the complaint submitted constitute a criminal offense, not a criminal act or not enough evidence led by Kabagwassidik / Kaurbinops or designated by warrant".

Before the case complaint degree phase begins, there are several steps that must be passed. Stages in the title of the complaint cases provided for in Article 7 and Article 8 of the General Criminal Investigation Perdir Central Java Regional Police No. 2 of 2015 on Complaint degree following cases:

\section{Article 7}

Implementation stage complaints of titles includes:
a. preparation;
b. implementation;
c. continuation complaints of degree results.

Article 8

The preparation stage includes:
a. degree of exposure complaint preparing the case is, by Bagwasidik / Urbinops;
b. infrastructure setup complaints title case
As for the purpose of implementation of title complaint cases, namely: ${ }^{7}$
a. determine the status of the criminal case or not;
b. formulate a plan of investigation;
c. define the elements chapter presupposed;
d. determining witnesses, suspects, and evidence;
e. specify a target date; and
f. Application of the techniques and tactics of Investigation.

\footnotetext{
${ }^{7}$ Article 9 of the General Criminal Investigation Perdir Central Java Regional Police No. 2 of 2015 on Title Complaint Cases
} 


\subsection{Benefits Effectiveness of Crime Investigation Complaint Held Through Case Central Java Police Jurisdiction Based Perdir General Central Java Regional Police No. 2 Of 2015 On Case Complaint degree.}

General Criminal Investigation Perdir Central Java Regional Police No. 2 Of 2015 About the Complaint Case Holds published and has been adapted to the principles of public service delivery is effective and efficient. There are at least ten joint service should be implemented by the agency or unit of work in a department that serves as a public service units, namely: ${ }^{8}$

- Simplicity

Public service procedure is straightforward, easy to understand and easy to implement.

- Clearly

- Technical and administrative requirements of the public service.

- Unit labor / official authority and responsibility in providing services and settlement of complaints / issues / disputes in the implementation of public services.

- Details of the cost of public services and the manner of payment.

- Certainty

Time of public services can be completed within a predetermined time.

- Product Accuracy public services is received correctly, proper and legitimate.

- Process and product safety public service to provide security and legal certainty.

- Leadership Responsibilities public service providers or appointed official responsible for the provision of services and resolution of complaints / problems in the implementation of public services.

- Infrastructures completeness availability and quality of infrastructure, equipment and other appropriate support including the provision of telecommunications and information technology.

- Ease of Access Points and the location and service facilities were adequate, easily accessible by the public, and can make use of telecommunications and information technology.

- Discipline, Modesty and care giver hospitality should be disciplined, polite, and courteous, friendly, and provide services with sincerity.

- Environmental comfort care should be orderly, organized, provided a comfortable waiting room, clean, tidy, beautiful environment and healthy and are equipped with supporting facilities services.

Basically complaints from the public is positive feedback that is constructive. With the increasing public demand for good governance and true service (good governance) of the police, then the priority on service activities is a must. To that end, the Central Java Police to give top priority in ministry on complaints from the public. Good service, efficient and effective will provide new hope and a sense of justice in society terjaminya transparent public finance management and direction.

\footnotetext{
${ }^{8}$ Minister for Administrative Reform Decree No. 63 of 2003 on Public Services
} 
Clearly also the reason of the publication of the General Criminal Investigation Perdir Central Java Regional Police No. 2 Of 2015 About the Complaint Case Holds described in Article 2 as follows:

- as a guideline in the implementation of title complaint cases made and mailed a complaint to the Police and within the framework of supervision / control of the investigation process;

- the implementation of the implementation of title complaint against a professional manner so as to create quality assurance handling complaints objectively and proportionately.

The effectiveness of the General Criminal Investigation Perdir Central Java Regional Police No. 2 Of 2015 On Case Complaint degree is described as follows: ${ }^{9}$

- that in order to carry out the duties and functions of the Indonesian National Police, particularly in improving service to the public about the complaint made and submitted in writing, the need for standards concerning mechanisms for receiving reports of complaints;

- that in the framework of the organization of the main tasks of police forces of the Republic of Indonesia and the tasks of the police as a translation as main tasks, the Indonesian National Police in general is authorized to issue regulations within the scope of authority of the Police Department Police administration;

- c. that for the creation of a professional investigation, proportionate, transparent and accountable necessary analytical work to the complaint that goes to the Police so that future investigations of service quality assurance materialize to the maximum so as to eliminate or reduce the complaints of society

- d. that to achieve factual truth substance of the complaint coming from the public, while on the other hand investigators encountered some obstacles in collecting facts / evidence, checking and testing of factual truth or the substance of the complaints received from the complainant, it should be deployed through the instrument title case

- e. that considerations referred to in paragraphs $a, b, c$, and d, this Regulation of the Director General of Criminal Investigation in Central Java Regional Police about the degree Complaint Cases ,

\section{Closing}

\subsection{Conclusion}

- General Criminal Investigation Perdir Central Java Regional Police No. 2 of 2015 concerning Complaint Case Holds issued to accommodate the creation of good service quality, and it is also one of reflection changes in work culture of the police in serving the public complaints in the context of good goverment and clean governance.

- General Criminal Investigation Perdir Central Java Regional Police No. 2 Of 2015 About the Complaint Case Holds facilitate the flow of complaints in order to achieve effectiveness and time efficiency of investigation by the Central Java Police personnel in response to any complaints from the public.

\footnotetext{
${ }^{9}$ Interview with Ipda Totok G III Sub Title Case Central Java Police On Date August 62018
} 


\subsection{Suggestion}

Basically complaints from the public is positive feedback that is constructive. With the increasing public demand for good governance and true service (good governance) of the police, then the priority on service activities is a must. Good service, efficient and effective will provide new hope and a sense of justice in society terjaminya transparent public finance management and direction. General Criminal Investigation Perdir Central Java Regional Police No. 2 Of 2015 About Case accommodates Complaints degree and requires that every officer in the service of public complaints to be able to understand the differences in the complaint.

\section{Bibliography}

[1] Adami Chazawi 2007. Pelajaran Hukum Pidana 2 Penafsiran Hukum Pidana Dasar Peniadaan Pemberatan dan Peringanan Kejahatan Aduan Perbarengan dan Ajaran Kausalitas. Raja Grafindo Persada. Jakarta.

[2] Adami Chazawi,2002. Pelajaran Hukum Pidana Bagian I Raja Grafindo Persada Jakarta.

[3] Adi Hamzah 2012. Hukum Acara Pidana Indonesia Sinar Grafika Jakarta.

[4] Andi Hamzah,2014. Hukum Acara Pidana Sinar Grafika Jakarta.

[5] Ediwarman,2010. Monograf Metodologi Penelitian Hukum Medan: Program Pascasarjana Univ. Muhammadiyah Sumatera Utara Medan.

[6] Esmi Warassih 2005. Pranata Hukum Sebuah Telaah Sosiologis Surya Alam Utama Jakarta.

[7] Fuad Usfa dan Tongat 2004. Pengantar Hukum Pidana UMM Press Malang.

[8] Hartono 2010. Penyidikan dan Penegakan Hukum Pidana Melalui Pendekatan Hukum Progresif Sinar Grafika Jakarta.

[9] M.Yahya Harahap. 2010 Pembahasan Permasalahan dan Penerapan KUHAP Penyidikan dan Penuntutan Sinar Grafika Jakarta.

[10] Mohammad Ekaputra 2010. Dasar-Dasar Hukum Pidana Indonesia USU Press Medan.

[11] Mohammad Taufik Makarao dan Suhasril 2002. Hukum Acara Pidana dalam Teori dan Praktek Ghalia Indonesia Jakarta.

[12] P.A.F Lamintang. 1997 Dasar-Dasar Hukum Pidana Indonesia Penerbit Citra Aditya Bakti Bandung.

[13] R. Soesilo 1990. Kitab Undang-Undang Hukum Pidana. Serta Komentarnya Pasal Demi Pasal Politeia. Bogor.

[14] Samidjo 1985. Pengantar Hukum Indonesia Armico. Bandung.

[15] Satjipto Raharjo 2009. Masalah Penegakan Hukum Suatu Tinjauan Sosiologis. Sinar Baru Bandung.

[16] Sri Wulandari 2013 Fungsi Laporan dan Pengaduan Masyarakat Bagi Penyidik Dalam Mengungkap Kejahatan Serat Acitya-Jurnal IImiah UNTAG Semarang No. 1.

[17] Soekanto Soerjono. 2014. Faktor-faktor yang Mempengaruhi Penegakan Hukum. RajaGrafindo Persada. Jakarta. 
[18] Soerjono Soekamto dan Sri Mamudji 2001 Penelitian Hukum Normatif Suatu Tinjauan Singkat Raja Grafindo Persada. Jakarta.

[19] Constitution of the Republic of Indonesia in 1945.

[20] The Code of Criminal Procedure

[21] Act No. 2 of 2002 on the Indonesian National Police.

[22] General Criminal Investigation PERDIR Central Java Regional Police No. 2 Of 2015 On Case Complaint degree.

[23] Robert B. Seidman \& Wiliam J. Chambles Law Order and Power Printed in the United States of America Published Stimulant Costly in Canada Library of Congress Catalog Card No. 78-111948. 